\title{
SIMULATING AN APPLIED MODEL TO OPTIMIZE CELL PRODUCTION AND PARTS SUPPLY (MIZUSUMASHI) FOR LAPTOP ASSEMBLY
}

\author{
Hidetaka Ichikawa \\ Faculty of Law, Economics and Humanities \\ Kagoshima University \\ Kohrimoto 1-21-30, Kagoshima, Kagoshima 890-0065, JAPAN
}

\begin{abstract}
This study investigates the optimal production system in Japan using a large-scale sampling survey of laptop assembly production firm. In Japan, many companies adopt a cell production system which is studied and emulated by other manufacturing companies around the world. Companies which successfully introduced the cell production process have improved their manufacturing, but related processes such as parts supply have not been optimized. If the supply of parts is inefficient, overall efficiency suffers even if cell production works optimally. In fact, it is absolutely necessary to pursue a total optimization. Thus, this paper considers the manufacturing system's needs in terms of the most suitable number of material handlers to supply parts(=Mizusumashi) from receiving area to the cells as it is linked to efficient cell production for laptop assembly using simulation.
\end{abstract}

\section{INTRODUCTION}

Consumer preferences and the diversification of values determine a strong demand for various products with their own characteristics, which makes product life cycles shorter. If there is not a clear difference between products, the determining factor for consumers is whether the products delivered to consumers according to their very specific demands.

Therefore it may be important to achieve instant product delivery. This can be done in the manufacturing process by considering how you can reduce the production lead time. Product lead time is the time interval from the receipt of an order to the shipment of the product.

But in order to establish short delivery times, the system of holding extra parts as stock or extra work-in-process during the manufacturing process is not good because of pressure on the company's finances. In situations in which production of small quantities of many different products is needed, small lot size requires that the setup must be changed often. However, lengthy setup time such as several hours fails to meet the demands of consumers. To win consumers, we should make the setup times shorter. This therefore requires a revolutionary product system, based on a so-called single setup which takes just 10 minutes. To achieve this objective, many kinds of companies have adopted TOYOTA PRODUCTION SYSTEM(TPS), LEAN THINKING, and Japanese human resource management concepts (Hamel and Prahalad 1989, Womack and Jones 1996).

Cell production is the manufacturing system which is used to overcome the above issues. In Japan, cell production was adopted by many companies from 1990 and now is used by not only Japanese companies but also many non-Japanese companies. The continuing use of cell production confirms productivity benefits such as:

- being able to respond to fluctuations in production

- requires less work-in-process inventory

- increases the morale of workers

- maximizes the improvement of productivity

- enables short production lead time

- increases of quality awareness and decreases defective rates

- requires less capital investment

- reflects immediately in the effect of kaizen

In this study of Plant-Y of Company-N which assembles laptops, the introduction of cell production achieved significant gains in productivity. In this example, increasing the consistency between each process makes it possible to get a competitive advantage (Clark and Fujimoto 1990). 


\section{Ichikawa}

However, as a kaizen method, we must be concerned with the production system totally, from the delivery of parts through to the finished product shipments. By eliminating waste in all processes from materials, production, through to shipment, high quality, low cost and short lead time can implemented efficiently (Womack, Jones, and Roos 1991, Womack and Jones 1996).

This study considers the importance of parts supply by mizusumashi. A mizusumashi is a material handler who supplies, using kanban, only the necessary items in the necessary quantities at the necessary time, that is, just-in-time. Accordingly, the mizusumashi's work strongly affects overall productivity of the assembly cells. The analysis of laptop assembly using cell production including mizusumashi is not judged from the objective of partial optimization but total optimization.

\section{FEATURES AND BENEFITS OF INTRODUCING CELL PRODUCTION}

The features of laptop assembly based on cell production in Company-N Plant-Y are having a relay production system, parts supply using kanban and mixed flow production. A relay production system is the mechanism to eliminate fluctuations in production between the processes autonomously. Parts supply uses kanban to supply the materials from the parts manufacturer to the assembly process by mizusumashi. Mixed flow production is necessary to respond to the diversification of market demand and production of small quantities of many products. Most notably, this plan includes 20,000 varieties of laptops and these products are built to order (BTO). A BTO process helps to avoid excess inventories of finished goods.

The results from the introduction of cell production over four years are:

- $\quad$ reduced floor area, about $10000 \mathrm{~m}^{2}$, by reducing parts inventory

- $\quad$ average days inventory reduced by half

- $\quad$ productivity increased 6.5times, with a laptop produced per 3 4 seconds, or 8000 units per day

- $\quad$ reduced production area per cell: from $22 \mathrm{~m}^{2}$ to $8.6 \mathrm{~m}^{2}$

The introduction of cell production makes it possible to produce a small variety of many products and to greatly eliminate waste in time and area. These production methods increase production efficiency and take minimal time needed to setup (Isa and Tsuru 2002; Sakamaki 2006; Shinobu and Mori 2003). All cell workers can observe by anteroposterior processes, which increases communications between workers, and it makes production more efficient. (Xie, Song, and Stringfellow 2003; Leenders and Wierenga 2002; Sethi and Nicholson 2001).

\section{CELL PRODUCTION MODEL AT COMPANY-N PLANT-Y}

Productivity in the cells determines the work of mizusumashi. If problems occur in the assembly cell, it negatively influences parts supply (=mizusumashi). In this factory, the cell manufacturing area applies kaizen constantly, and at a very sophisticated level. The efficiency of a mizusumashi's work depends on the productivity of cell manufacturing. Therefore we describe in detail how cell manufacturing performs, in order to clarify the problem of concern to this study.

\subsection{Analysis of Cell Production}

Figure 1 depicts the work in this cell production study which can be divided into four broad processing categories ; assembly process, pre-production/aging inspection process, post- production/aging inspection process and packing process.

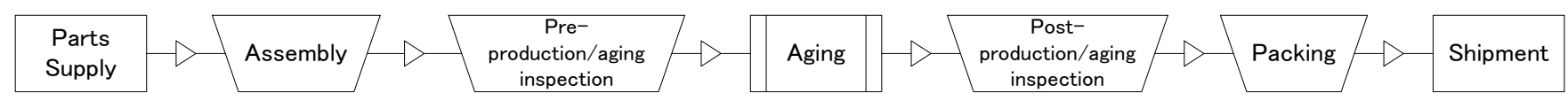

Figure 1: Work flow of assembly of laptops

Table 1 shows the operating schedule which is allotted to each cell worker. Worker 2 has production/aging inspection during work and has 10,7 inspection operations respectively.

In addition figure 2 depicts the animation of cell production whilst figure 2 shows how the working areas for Worker 2 are set in work units because waiting time is included in Worker 2's operating time. This makes it possible to minimize waiting time as much as possible. 


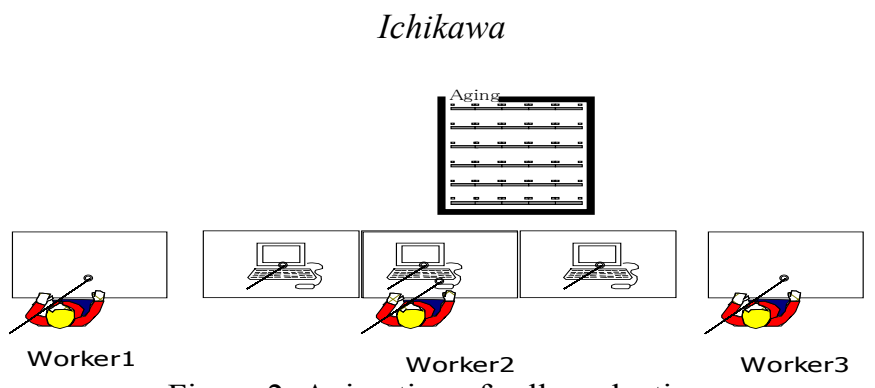

Figure 2: Animation of cell production

Equipment and operators are located to ensure an efficient layout, and the most efficient production process arrangement maximizes profit. In the above conditions, each worker operates their own process. Worker 1 and Worker 3 do not have any waiting time, but Worker 2 does, making it difficult to divide all work evenly. As a result, it is important that Worker 2 operates smoothly in order to increase productivity.

Table 2 shows work categories for each worker based on table 1. The following section, while continuing work analysis, will also analyze cell production by simulation. Standridge and Marvel (2006) reveal that the analysis of lean production system needs simulation, consequently, a module-based simulation is used (Nomura and Takakuwa 2004) which will reveal the effect of cell production.

Table 1: Operation schedule

\begin{tabular}{|c|c|c|c|}
\hline & & Operation time(sec.) & Waiting time(sec.) \\
\hline \multicolumn{4}{|c|}{ Operation : Assembly } \\
\hline $1-1$ & take out a base & 4.0 & 0 \\
\hline $1-2$ & take off a keyboard, a keyboard cover, a switch board, and thermal plate & 16.0 & 0 \\
\hline $1-3$ & set up a CPU & 3.1 & 0 \\
\hline$\cdot$ & (Omitted) & . & $\cdot$ \\
\hline $1-29$ & set up a HDD cover & 3.8 & 0 \\
\hline $1-30$ & screw (2pcs.) & 3.6 & 0 \\
\hline $1-31$ & set up a battery : End of assembly operation & 3.0 & 0 \\
\hline \multicolumn{4}{|c|}{ Operation : pre-production/aging inspection } \\
\hline $2-1$ & plug in & 2.3 & 0 \\
\hline $2-2$ & insert test material ; turn on & 3.4 & 0 \\
\hline $2-3$ & plug in printer loop and RTC PC-connecter & 3.4 & 0 \\
\hline $2-4$ & initialization & 16.5 & 20 \\
\hline $2-5$ & write data from FD to HDD & 1.6 & 85 \\
\hline $2-6$ & write PMI information & 7.4 & 0 \\
\hline $2-7$ & set up aging time & 9.3 & 33 \\
\hline · & Omitted) & . & . \\
\hline$\overline{2-19}$ & make sure USB port & 1.8 & 45.7 \\
\hline $2-20$ & insert inspection FD; end up inspection & 5.1 & 0 \\
\hline \multicolumn{4}{|c|}{ Operation : post-production/aging inspection } \\
\hline $3-1$ & connct CRT terminal post and turn on & 3.7 & 0 \\
\hline $3-2$ & connct LAN cable and Card Pass, audio cable, Svideo terminal & 5.5 & 0 \\
\hline $3-3$ & plug the numeric keypad and mouse terminal, wait hold it & 2.4 & 38.7 \\
\hline & tted) & . & . \\
\hline $3-27$ & check for extraneous material & 34.6 & 0 \\
\hline $3-28$ & check for shortage of screw & 13.0 & 0 \\
\hline $3-29$ & lattach the serial number seal & 13.2 & 0 \\
\hline \multicolumn{4}{|c|}{ Operation : Packing } \\
\hline $4-1$ & pull out container & 1.7 & 0 \\
\hline . & & . & . \\
\hline $4-7$ & finish after confirmation & 0 & 0 \\
\hline
\end{tabular}




\section{Ichikawa}

Table 2: operation category in cell production

\begin{tabular}{c|r}
\hline & \multicolumn{2}{|c}{ Work Category } \\
& (the consistency of operation number on table 1) \\
\hline Worker1 & $1-1 \sim 1-31$ \\
\hline Worker2 & $2-1 \sim 3-23$ \\
\hline Worker3 & $3-24 \sim 4-7$ \\
\hline
\end{tabular}

\subsection{Simulation of Cell Production}

Table 3 shows the parameter of operations by each worker at simulation of cell production(The number of table 3 is consistent with that of table 1,2). Workers 1, 2 and 3 have an operating time of 222.8 seconds, 973.5 seconds (including 608.7 seconds waiting time), 150.6 seconds respectively. Workers 1 and 3 do not have any waiting time, therefore, their parameters for operating time are tria $(222.8,267.36,2289.64)$ and tria $(150.6,180.72,195.78)$ respectively. But since Worker 2 has waiting time, when that waiting time occurs, he tries to find another working area and continues to work. Figure 3 consequently depicts the work flow diagram of the Worker 2's operation.

Table3: List of parameters of each worker

\begin{tabular}{|c|c|c|c|}
\hline & Operation & Operation Time & Waiting Time \\
\hline Worker1 & $1-1 \sim 1-31$ & TRIA(222.8, 267.36, 289.64) & \\
\hline \multirow{17}{*}{ Worker2 } & $2-1 \sim 2-4$ & $\operatorname{TRIA}(25.6,30.72,33.28)$ & 20 \\
\hline & $2-5^{\prime}$ & $\operatorname{TRIA}(1.6,1.92,2.08)$ & 85 \\
\hline & $2-6 \sim 2-7$ & TRIA $(16.7,20.04,21.71)$ & 33 \\
\hline & $2-8$ & $\operatorname{TRIA}(1.3,1.56,1.69)$ & 17.7 \\
\hline & $2-9 \sim 2-15$ & TRIA(27.0, 32.4, 35.1) & 34.9 \\
\hline & $2-16$ & TRIA $(11.2,13.44,14.56)$ & 78.3 \\
\hline & $2-17^{\prime}$ & $\operatorname{TRIA}(4.6,5.52,5.98)$ & 22 \\
\hline & $2-18$ & $\operatorname{TRIA}(1.5,1.8,1.95)$ & 23 \\
\hline & $2-19^{\prime}$ & $\operatorname{TRIA}(1.8,2.16,2.34)$ & 45.7 \\
\hline & $2-20^{\prime}$ & $\operatorname{TRIA}(5.1,6.12,6.63)$ & \\
\hline & $3-1 \sim 3-4$ & TRIA $(11.6,13.92,15.08)$ & 38.7 \\
\hline & $3-5 \sim 3-9$ & TRIA $(64.5,77.4,83.85)$ & 34 \\
\hline & $3-10 \sim 3-11$ & $\operatorname{TRIA}(3.0,3.6,3.9)$ & 20.2 \\
\hline & $3-12 \sim 3-13$ & TRIA(3.8, 4.56, 4.94) & 40.6 \\
\hline & $3-14 \sim 3-16$ & $\operatorname{TRIA}(6.8,8,16,8,84)$ & 98.3 \\
\hline & $3-17 \sim 3-20$ & TRIA(61.0,73.20,79.3) & 17.3 \\
\hline & $3-21$ & TRIA $(4.8,5.76,6.24)$ & \\
\hline Worker3 & $4-1 \sim 4-7$ & TRIA(150.6, 180.72, 195.78) & \\
\hline
\end{tabular}

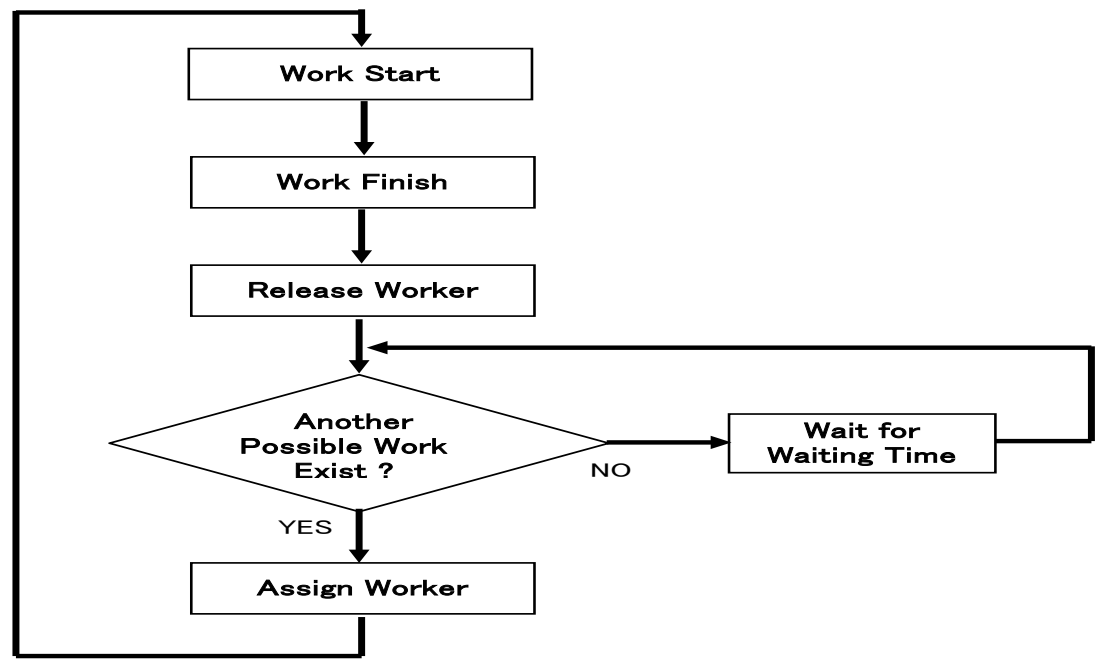

Figure 3: Work flow of worker 2 


\section{Ichikawa}

As in the case of Company-N Plant-Y, if a worker doesn't work efficiently and the product flow suffers, we set up the parameters of a model to include help in the next task. Since a one-piece flow manufacturing system is being implemented in this plant, it is also a reliable production flow method and suitable for producing small quantities of many varieties of products. From above, it makes possible to create the simulation model that reflect the actual cell production.

\section{A MODEL FOR SUPPLYING PARTS (MIZUSUMASHI) AT COMPANY-N PLANT-Y}

\subsection{Current Model of Parts Supply by Mizusumashi}

To survey the entire process, figure 4 depicts from the delivery by the supplier using kanban by the just-in-time method, and the supply of parts to the parts pile. Mizusumashi picks up the parts needed for production, supplies them to the stock for the cell production area. Next, each worker produces laptop on schedule. The finished products are sent to the shipment section.

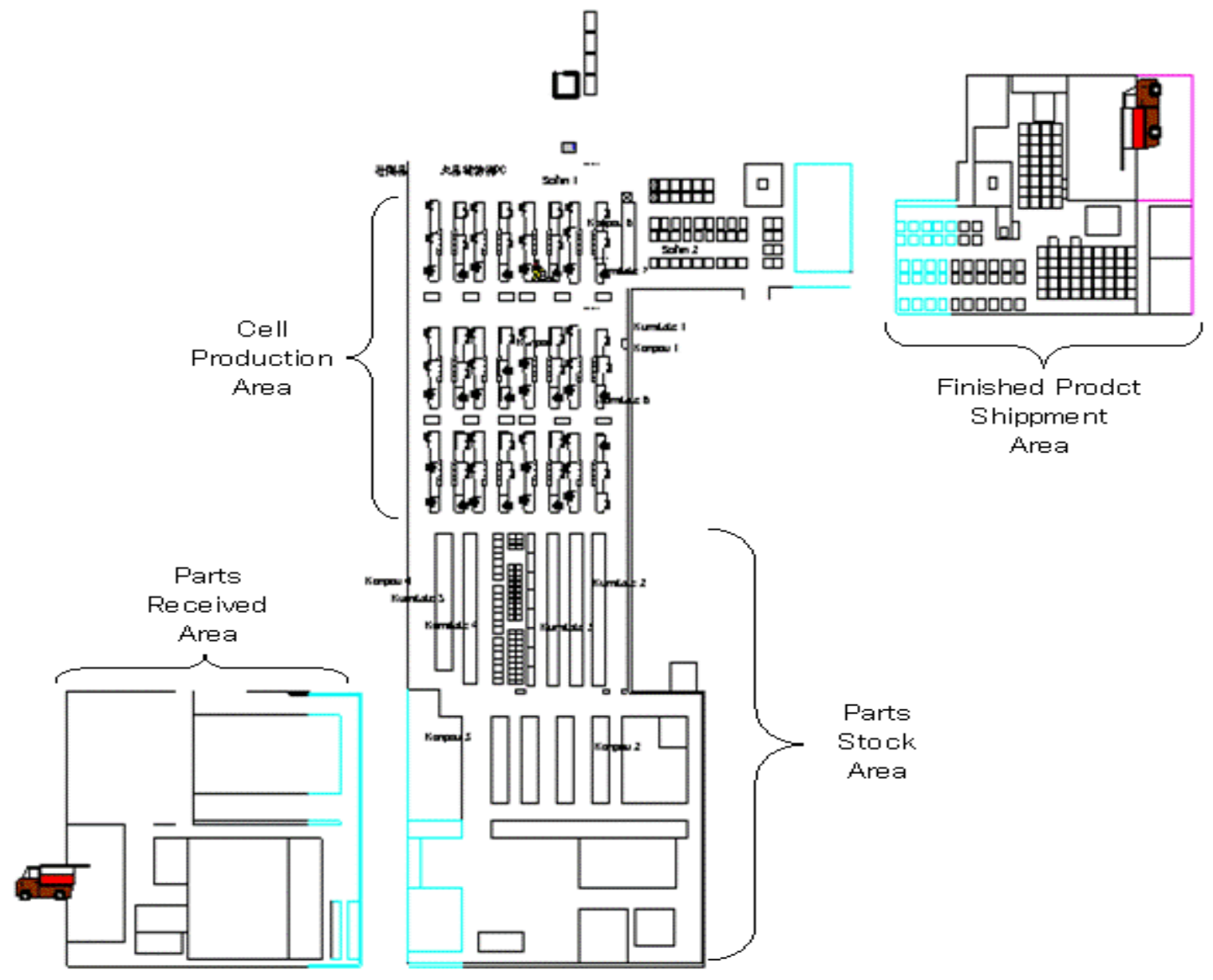

Figure 4: Overall animation at Company-N Plant-Y

Finally, from here these products are shipped to the each dealer. Just-In-Time (JIT) is a system in which necessary items are received just in time as they are needed in the production line. It forces a synchronization of all production-related processes. The Just-In-Time production system decreases the lead-time of products, and is one of the two pillars of the Toyota Production System. The effect of the system is demonstrated below in the continuous flow of products (Liker 2003) which are important roles for the analysis of this model. This plant is in the process of establishing a production flow based on JIT. Every process operates according to the production flow, and all workers try to maintain a continuous flow of products in this plant. 


\section{Ichikawa}

\subsection{The Work of Mizusumashi}

In this current model, one mizusumashi supplies parts to 2 cell areas, accordingly there are 16 mizusumashis to service the 32 cell areas.

Mizusumashi can set up to 36 units of parts on each parts place. This condition is determined by the number maximized for one enclosure. This is because an enclosure is the biggest part of all, and every part delivers units per laptop.

Instructions supplied to mizusumashi are implemented at the terminal next to the aisle. Mizusumashis receive an instruction sheet for a product of and the number of parts, they go to the parts stock area to pick up parts needed at 6 locations and go to the cell production area to supply parts needed by rotation. When it is determined, they should pick up all the parts needed to produce laptops. And they move around about 400 500m per a parts supply.

\subsection{The Problem with the Current Model}

The problem with current model is that mizusumashi must wait when an instruction supplied doesn't exist or the parts stock area is full because the production is not yet complete. Moreover, the timing that mizusumashi will supply is decided by personal judgment. Mizusumashi have to check the parts area several time to see whether necessary parts should be supplied.

This set of one mizusumashi per two cell areas was determined by the manager's tacit knowledge, but waiting time often occurs in the process of parts supply system, therefore we need to consider the elimination of waiting time as in cell production and TPS.

\subsection{Kaizen Model}

In order to resolve above problem, we incorporate the following elements in the kaizen model:

(1) not limited to specific cell area, all mizusumashis can obtain supply parts needed from any of the 32 cell areas.

(2) one supply lot caters for 24 units of part

(3)the timing of parts supply starts to instruct the part supply when there are less than 12 parts at the cell area's parts stock area. hours).

We simulate this improved model (kaizen model)under the terms of the above three conditions and 7-day running (168

Figure 5 depicts the flow of work and information that we simulate mizusumashi work to reflect condition (1). Figure 6 depicts stock trends under the conditions (2) and (3). We set up the module to start to instruct the parts supply when there are less than 12 remaining at the parts stock area of the cells (Figure 7). The conditions of kaizen model are to never have over 36 units at the cell area's stock area but also to never allow the shortage of parts, so as not to stop the continuous flow of production.

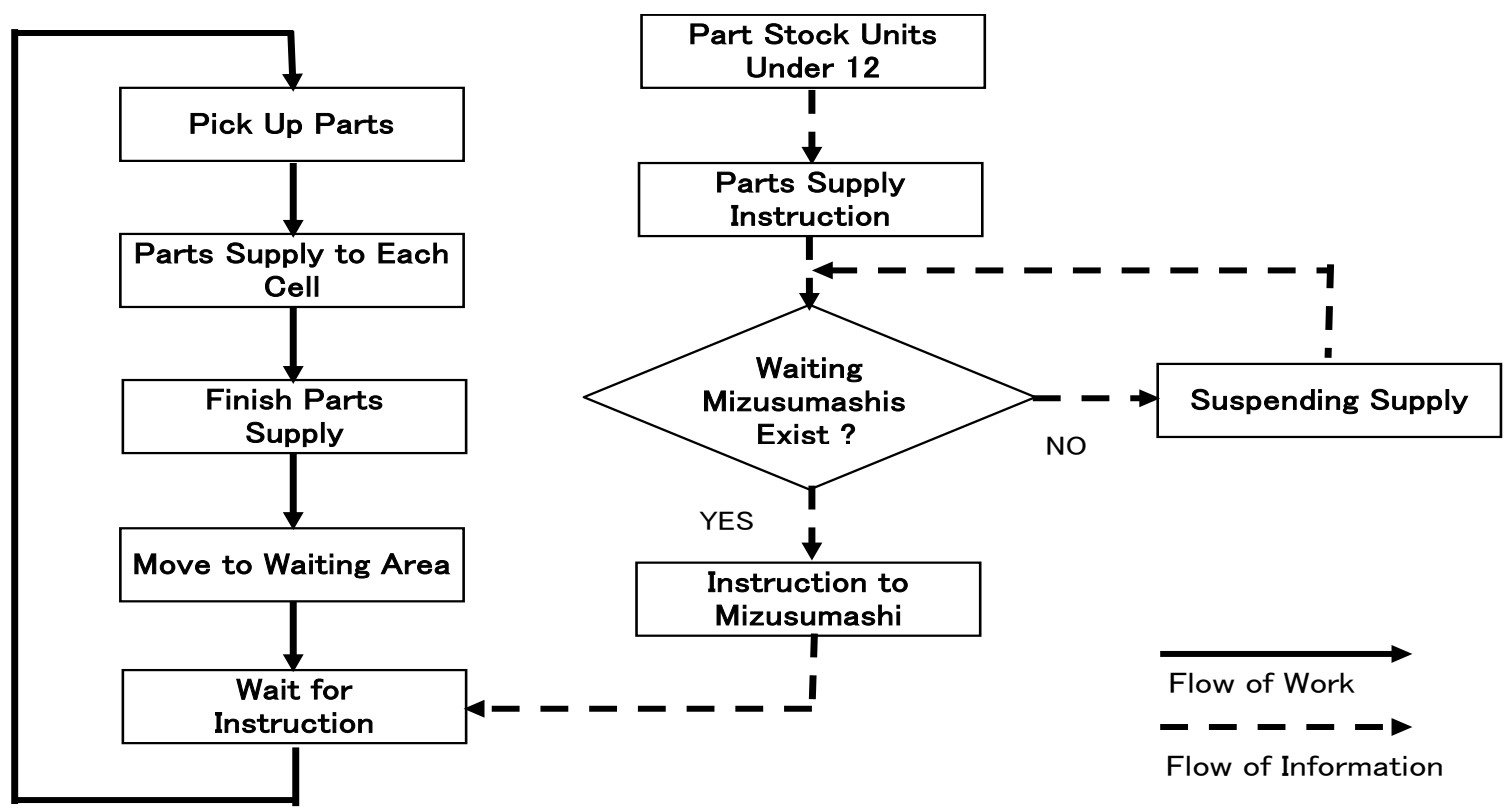

Figure 5: Flow diagram of mizusumashi work and information 


\section{Ichikawa}

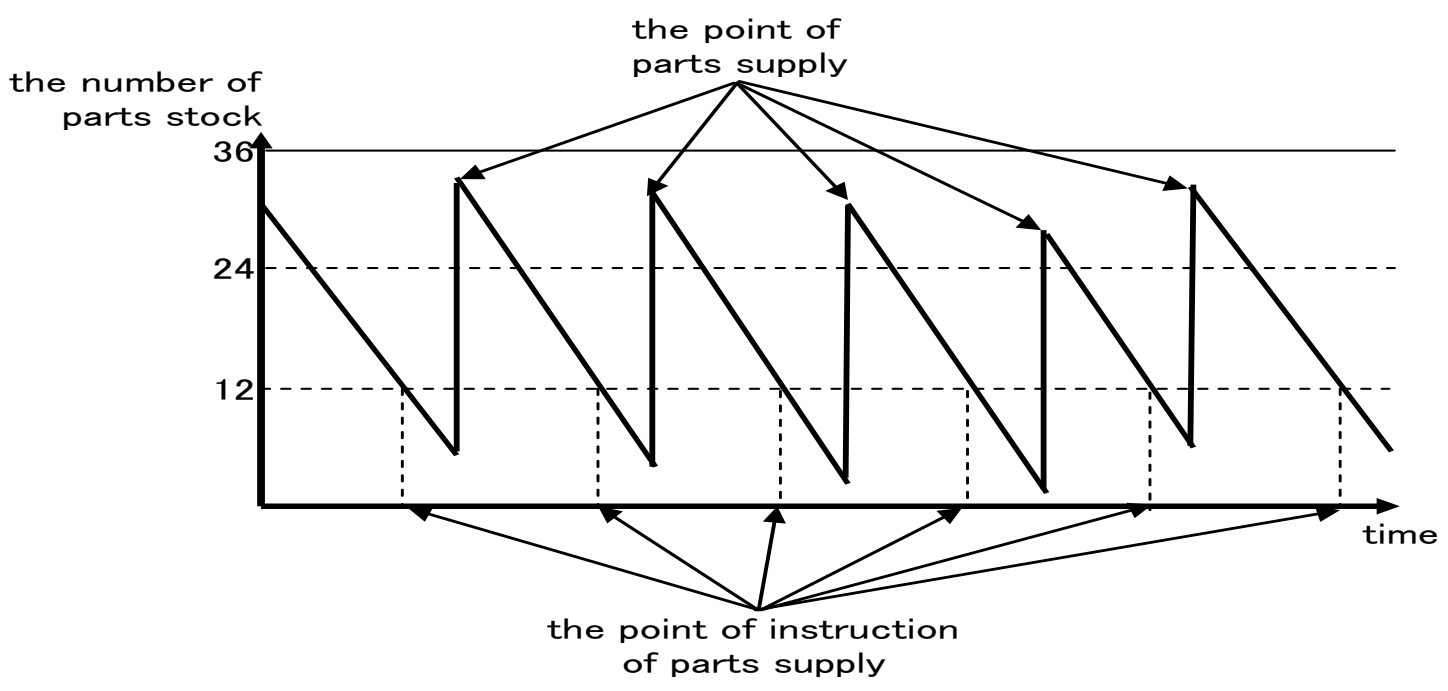

Figure 6: Shift in the number of parts stock at a cell

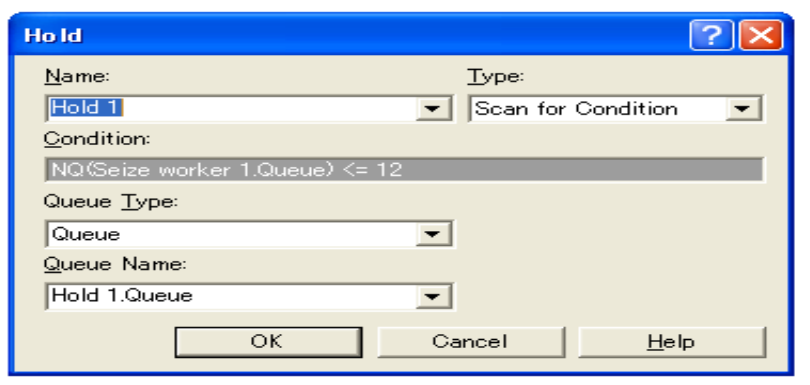

Figure 7: Module of instruction for parts supply

When mizusumashis pick up and supply parts, they stop at 8 locations which are 6 parts place, cell production area and terminal. Table 4 shows a list of parameter that mizusumashi supply parts.

This required a survey of the optimal number of mizusumashi using a module-based simulation based on ARENA (Kelton, Sadowski, and Sturrock. 2007), on the condition that cell production does not stop laptop production, nor cause a shortage of parts.

Finally, the kaizen model was compared to the current model, in order to analyze the advantages of the improved model (Tan and Takakuwa 2007).

Table 4: List of parameters of mizusumashi's traveling time

\begin{tabular}{|l|c|}
\hline & $\begin{array}{c}\text { traveling time(including } \\
\text { mizusumashi working time) }\end{array}$ \\
\hline terminal $\Rightarrow$ parts $\mathrm{A}$ & $\operatorname{TRIA}(80,100,120)$ \\
\hline parts $\mathrm{A} \Rightarrow$ parts $\mathrm{B}$ & $\operatorname{TRIA}(50,60,70)$ \\
\hline parts $\mathrm{B} \Rightarrow$ parts $\mathrm{C}$ & $\operatorname{TRIA}(30,40,50)$ \\
\hline parts $\mathrm{C} \Rightarrow$ parts $\mathrm{D}$ & $\operatorname{TRIA}(50,60,70)$ \\
\hline parts $\mathrm{D} \Rightarrow$ parts $\mathrm{E}$ & $\operatorname{TRIA}(70,80,90)$ \\
\hline parts $\mathrm{E} \Rightarrow$ parts $\mathrm{F}$ & TRIA $(40,50,60)$ \\
\hline parts $\mathrm{F} \Rightarrow$ cell production & TRIA $(60,70,80)$ \\
\hline cell production $\Rightarrow$ terminal & TRIA $(15,20,25)$ \\
\hline \multicolumn{2}{|c|}{ Time: in seconds TRIA $=$ Triangula }
\end{tabular}




\section{Ichikawa}

\subsection{The Result of Kaizen Model Simulation}

The result of the kaizen model is that the work stoppages caused by parts shortage at some cell areas when the number of mizusumashi are less than 11, can be eliminated if the number of mizusumashi are more than 12 they are able to supply parts appropriately. Figure 8 shows that the rate of work stoppages are 4.5, 11.8, 23.0\% in case of 11, 10, 9 mizusumashis respectively and work stoppage by parts shortage never occurs in case of more than 12 mizusumashis.

The rate of stoppage refers to the percentage of halt time in the cells, caused by the mizusumashi holding up the smooth supply of parts, for the total time of simulation (168 hours).

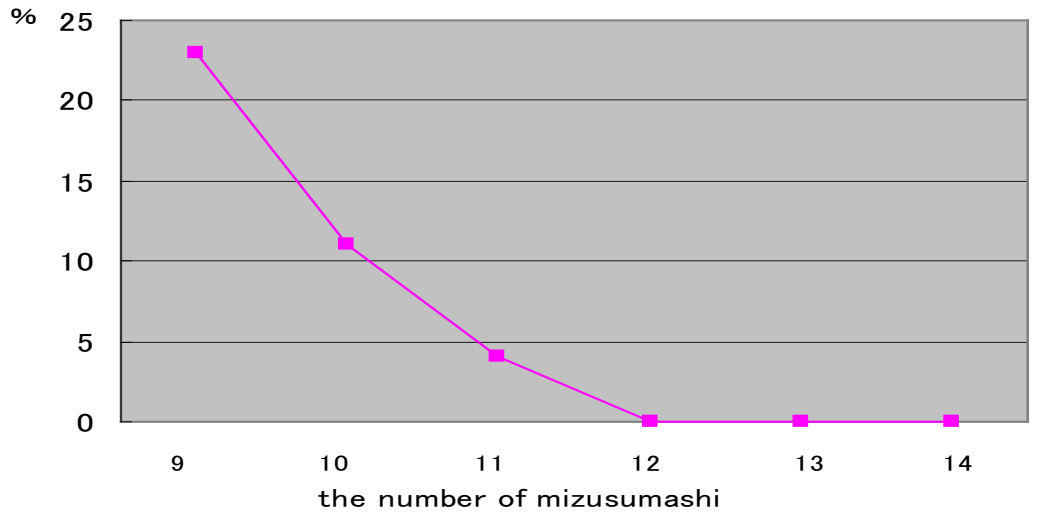

Figure 8: Number of mizusumashi and rate of work stoppage by parts shortage

\section{CONCLUSIONS}

Compared to the current model, we can reduce four mizusumashis and the reduced total of 12 mizusumashis can supply all necessary parts. This results in a personnel cost savings of one-fourth.

For improving the Japanese-style production system, tacit knowledge has an important role. As stated before, trial and error has improved production continuously by eliminating waste, and ensuring people pursue the most effective productivity methods.

For parts supply, however, this study makes it clear that there is still $25 \%$ inefficiency(4 mizusumashis). Using simulation makes the scale of improvement clearer, and makes it possible to pursue even leaner Lean Manufacturing. As can be seen, considering the mizusumashi's labor costs, the optimal number of mizusumashi is twelve, to achieve $100 \%$ productivity in all cells and cost minimization.

\section{REFERENCES}

Clark, K. B., and T. Fujimoto. 1990. The Power of Product Integrity. Harvard Business Review November-December 68(6):107-18.

Hamel, G., and C. K. Prahalad. 1989. Strategic Intent. Harvard Business Review May-June:63-76.

Isa, K., and T. Tsuru. 2002. Cell Production and Workplace Innovation in Japan: Toward a New Model for Japanese Manufacturing?. Industrial Relations Vol.41:548-578.

Kelton, W. D., R. P. Sadowski, and D. T. Sturrock. 2007. Simulation with ARENA. 4th ed. New York: McGraw-Hill.

Leenders, M. A. A. M., and B. Wierenga. 2002. The effectiveness of different mechanisms for integrating marketing and R\&D. Journal of Product Innovation Management 19(4):305-317.

Liker, J. K. 2003. The Toyota Way. New York: McGraw-Hill, Inc.

Nomura, J., and S. Takakuwa. 2004. Module-based modeling of flow-type multistage manufacturing systems adopting dualcard KANBAN system. In Proceedings of the 2004 Winter Simulation Conference, ed. R .G. Ingalls, M. D. Rossetti, J. S. Smith, and B. A. Peters, 1065-1072. Piscataway, New Jersey: Institute of Electrical and Electronics Engineers, Inc.

Sakamaki, H. 2006. Changing the way of thinking and company with cell System of CANON Way. Japan Management Association Management Center.

Sethi, R., and C. Y. Nicholson. 2001. Structural and contextual correlates of charged behavior in product development teams. Journal of Product Innovation Management 18(3):154-168. 


\section{Ichikawa}

Shinobu, C., and K. Mori. 2003. The design framework of cell manufacturing system. Japan Industrial Management Association Vol.5. No.6:491-495.

Standridge, C. R., and J. H. Marvel. 2006. Why lean needs simulation. In Proceedings of the 2006 Winter Simulation Conference, ed. L. F. Perrone, F. P. Wieland, J. Liu, B. G. Lawson, D. M. Nicol, and R. M. Fujimoto, 1907-1913. Piscataway, New Jersey: Institute of Electrical and Electronics Engineers, Inc.. Available via <http://www.informssim.org/wsc06papers/244.pdf> [accessed January 31, 2009].

Tan, Y., and S. Takakuwa. 2007. Predicting the impact on business performance of enhanced information system using business process simulation. In Proceedings of the 2007 Winter Simulation Conference, eds. S. G. Henderson, B. Biller, M.H. Hsieh, J. Shortle, J. D. Tew, and R. R. Barton, 2203-2211. Piscataway, New Jersey: Institute of Electrical and Electronics Engineers, Inc.

Womack, J. P., D. T. Jones., and D. Roos. 1991. The machine that changed the world. Harper Perennial, Inc.

Womack, J. P., and D. T. Jones. 1996. Lean thinking : Banish Waste and Create Wealth in Your Corporation (Lean Enterprise Institute). Simon \& Schuster.

Xie, J., M. Song, and A. Stringfellow. 2003. Antecedents and Consequences of Goal Incongruity on New Product Development in Five Countries: A Marketing View. Journal of Product Innovation Management 20(3):233-250.

\section{AUTHOR BIOGRAPHY}

HIDETAKA ICHIKAWA is a full-time instructor in Faculty of Law, Economics and Humanities at Kagoshima University. He received his B.A. in Economics from Nagoya City University in 1999 and M.A. degrees in Economics from Nagoya University in 2005. His research interests include product management systems including product and process innovation, TPS manufacturing system and human resources. His email address is<ichikawa@leh.kagoshima-u.ac.jp>. 